\title{
Effect of Urea Super Granule and Prilled Urea on Yield and Yield Attributes of Broccoli (Brassica oleracea var. italica L.)
}

\author{
M. J. Hussain ${ }^{1}$, A. J. M. S. Karim², A. R. M. Solaiman², M. S. Islam² \\ and M. Rahman ${ }^{3}$ \\ ${ }^{1}$ Soil \& Water Management Section, Horticulture Research Centre, Bangladesh Agricultural Research \\ Institute (BARI), Gazipur, Bangladesh; ${ }^{2}$ Dept. of Soil Science \& ${ }^{3}$ Dept. of Horticulture, Bangabandhu \\ Sheikh Mujibur Rahman Agricultural University, Gazipur, Bangladesh \\ *Corresponding author and Email: hussainmdjamal@ymail.com
}

Received: 03 October 2016

Accepted: 12 December 2016

\begin{abstract}
A field experiment was conducted at Bangabandhu Sheikh Mujibur Rahman Agricultural University, Gazipur during 2010-2011 to determine the effects and economic performance of urea super granule (USG) and prilled urea (PU) in terms of growth and yield of broccoli and to find out the optimum and economic doses of USG and PU for broccoli in Shallow Red-Brown Terrace Soil under Madhupur Tract. The experiment was laid out in a randomized complete block design with three replications having 17 treatment combinations constituted with different levels of urea super granule (USG) and prilled urea (PU). Result showed that yield of broccoli increased significantly with increasing rate of USG and PU. The treatments containing $160 \mathrm{~kg} \mathrm{~N}$ from USG and $180 \mathrm{~kg} \mathrm{~N}$ from PU exhibited the best performance on yield and yield contributing characters of broccoli having the head yield of 12.9 and 10.6 ton $\mathrm{ha}^{-1}$, respectively. All the yield contributing characters and the economic profitability were favorably correlated with these high yield performing treatments. The performance of USG in terms of growth, yield and yield attributes, head quality (compactness coefficient) and economic profitability was found significantly higher as compared to that of PU. Therefore, USG @ $160 \mathrm{~kg} \mathrm{~N} \mathrm{ha}^{-1}$ and PU @ $180 \mathrm{~kg} \mathrm{~N} \mathrm{ha}^{-1}$ along with other recommended fertilizers could be suggested for broccoli production in terms of yield and economics. From quadratic equation USG @ 163 and 160 kg N ha ${ }^{-1}$ and PU @ 169 and $160 \mathrm{~kg} \mathrm{~N} \mathrm{ha}^{-1}$ along with other recommended fertilizers could be suggested as optimum and economic doses for broccoli production in Silty Clay Loam Soil of Madhupur Tract.
\end{abstract}

Keywords: Broccoli, nitrogen, USG, yield attributes, economic profitability.

\section{Introduction}

In Bangladesh, broccoli is cultivated on a limited area. Farmers are not aware of the cultivation practices of broccoli and they use imbalanced fertilizers with a higher dose of nitrogenous fertilizer, which incurred a higher cost of production. Nitrogen is an important plant nutrient and is the most limiting element due to its high mobility and different types of losses (Zaman et al., 1993). To improve the $\mathrm{N}$ use efficiency urea super granule (USG) is one of the popular nitrogenous fertilizers and can be used for upland crops like broccoli, cabbage, cauliflower, brinjal, tomato, banana etc. like wetland rice crop (FRG, 2005). The application 
of USG guarantees the better utilization of $\mathrm{N}$ throughout the growing period and ensures high yield reducing the nitrate level by $20-30 \%$ (Wojciechowska, 2002). Hussain et al. (2003) showed that $20 \%$ urea could be saved by the use of USG instead of PU for cabbage, cauliflower and brinjal. The USG technology might have agronomic importance for upland or dryland crops (Haque, 2002) and deeper placement of USG can reduce $\mathrm{NH}_{3}$ and $\mathrm{NOx}$ emissions substantially compared with broadcast or mixed PU (Khalil et al., 2006). Nazrul et al. (2007) reported that 5-8 $\mathrm{cm}$ deep placement of USG in cabbage cultivation could save $20 \% \mathrm{~N}$ than PU.

Therefore, to control the loss and to improve fertilizer use efficiency USG application may be a good option to minimize production cost as well as to increase crop yield of broccoli. But there is a scanty of research findings to develop a fertilizer recommendation with USG for broccoli production. Keeping these views in mind the present study was undertaken to determine the effects of USG and PU on the growth and yield of broccoli, their economic performance and the optimum and economic doses of USG and PU for broccoli at Salna series of Madhupur Tract.

\section{Materials and Methods}

The experiment was conducted at the research field of the Department of Soil Science,
Bangabandhu Sheikh Mujibur Rahman Agricultural University during the period 20102011 with a view to assess the comparative performance of urea super granule (USG) and prilled urea (PU) and find out their optimum doses for broccoli production. The soil of the experimental field belongs to Salna series representing the Shallow Red Brown Terrace soil in Bangladesh soil classification system, which falls under the order Inceptisols in USDA Soil Taxonomy (Brammer, 1980; FAO, 1988).

The soil of the study area is silty clay loam in texture with sand, silt and clay 17.8, 45.6 and $36.6 \%$, respectively having bulk density $1.34 \mathrm{~g}$ $\mathrm{cm}^{-3}$, particle density $2.61 \mathrm{~g} \mathrm{~cm}^{-3}$, porosity $47.47 \%$ and field capacity $28.67 \%$. Chemical properties of initial soil were analyzed and presented in Table 1.

The experiment consisted of seventeen treatments comprising 8 levels $(80,100,120,140,160,180,200$ and $220 \mathrm{~kg} \mathrm{~N}$ ha ${ }^{1}$ ) of both USG and PU along with a control laid out in a randomized complete block design with three replications. Besides these a blanket dose of P, K, S, Zn, B, and Mo were applied for all treatments@53 kg P, 83 kg K, $20 \mathrm{~kg} \mathrm{~S}, 2.0 \mathrm{~kg}$ $\mathrm{Zn}, 1 \mathrm{~kg} \mathrm{~B}$ and $0.8 \mathrm{~kg} \mathrm{Mo} \mathrm{ha}{ }^{-1}$. Urea (USG and PU), TSP, MoP, gypsum, boric acid, zinc oxide and sodium molybdate were applied as a sources of N, P, K, S, B, Zn and Mo, respectively.

Table 1. Chemical properties of the initial soil of the experimental plot

\begin{tabular}{lc}
\hline Soil properties $(0-15 \mathrm{~cm}$ soil depth) & Analytical value \\
\hline Soil $\mathrm{pH}$ & 5.97 \\
Organic carbon $(\%)$ & 0.96 \\
Total N $(\%)$ & 0.10 \\
Available $\mathrm{P}(\mu \mathrm{g} / \mathrm{g})$ & 14.18 \\
Exchangeable K $(\mathrm{c}-\mathrm{mol} / \mathrm{kg}$ soil $)$ & 0.32 \\
Available $\mathrm{S}(\mu \mathrm{g} / \mathrm{g})$ & 13.78 \\
Available B $(\mu \mathrm{g} / \mathrm{g})$ & 0.21 \\
$\mathrm{CEC}(\mathrm{c}-\mathrm{mol} / \mathrm{kg}$ soil $)$ & 12.67 \\
\hline
\end{tabular}


The high yielding broccoli variety Premium crop (Brassica oleracea var. italica L.) was used as a test crop collected from Taki seed company, Japan. After proper land preparation, 25-day-old healthy broccoli seedlings were transplanted in lines on November 20, 2010 maintaining a rowto-row and plant-to-plant distance of 60 and 45 $\mathrm{cm}$, respectively. Each plot was watered uniformly at every alternate day by watering can to bring the soil moisture at desired level up to stand establishment. Weeding was done twice just before at first and second top dressing. Earthing up was done to make a continuous line of ridges and furrows. After stand establishment furrow irrigation was given at an interval of 7 days up to harvesting. All the fertilizers with $50 \%$ MoP except PU and USG were applied as broadcast and incorporated during final land preparation. Prilled urea was top-dressed in two equal splits at 15 and 35 DAT as ring method around the plant by proper mixing with the soil. At 15 DAT USG was placed at 7-8 $\mathrm{cm}$ below the surface, 9-10 cm apart from plant base. The rest $50 \%$ MoP was top-dressed at 15 DAT followed by irrigation (depending on soil moisture status).

The crop was harvested when the head or inflorescence was at commercial maturity, just started to swell but before opening the flower bud. The entire plants including the head and roots were harvested very carefully with the help of a shabol and data on total weight, root weight, leaf number, head weight and yield were recorded soon after harvesting. Before harvesting head diameter and after harvesting head length were measured by using a centi-meter scale. The weight of individual head was taken including the stalk with three young leaves of the broccoli plant and the marketable portion of the plant was considered to the extent of about $15 \mathrm{~cm}$ from the top of the inflorescence along the stem according to Liu et al. (1993). Nitrogen uptake by the crop from soil was calculated by using the formula:

Nitrogen uptake $\left(\mathrm{kg} \mathrm{ha}^{-1}\right)=\frac{\% \text { Nitrogen } \times \mathrm{Y}\left(\mathrm{kg} \mathrm{ha}^{-1}\right)}{100}$

Here,

$\%$ Nitrogen $=$ Average nitrogen content $(\%)$ of plant biomass
$\mathrm{Y}\left(\mathrm{kg} \mathrm{ha}^{-1}\right)=$ Total dry matter production of plant biomass

Nitrogen use efficiency (NUE) was determined by the ratio of $\mathrm{N}$ in the crop at harvest compared to $\mathrm{N}$ applied by subtracting the uptake made by the control plot. The efficiency of applied fertilizer $\mathrm{N}$ may be quantified by the following equation as stated by Craswell and Godwin (1984):

Apparent $\mathrm{N}$ recovery $(\mathrm{NUE})=((\mathrm{N}$ uptake $\mathrm{F}-\mathrm{N}$ uptake C)/ Fertilizer $\mathrm{N}$ applied) $\times 100$

Where,

$\mathrm{F}$ and $\mathrm{C}$ denote fertilized crop and unfertilized control, respectively.

The collected data were compiled and tabulated in proper form and statistical analysis was done using the statistical package MSTATC. Computation and preparation of graphs were made using Microsoft Excel 2003 program. Economic evaluation of different treatment combinations was done through partial budgeting followed by marginal analysis of the cost-benefit as suggested by Perrin et al. (1979).

\section{Results and Discussion}

\subsection{Plant growth in relation to plant height}

Plant growth as affected by PU and USG in relation to plant height of broccoli at different DAT was increased followed by a sigmoid graphical form (Figure 1). It was revealed that plant growth in relation to plant height of broccoli increased significantly with increasing the age of crop and it was rapidly increased up to 50 DAT and then slower with the maximum level of plant height $(70.66 \mathrm{~cm})$ at 70 DAT. The highest plant height $(70.66 \mathrm{~cm})$ was recorded from the treatment of USG-N $\mathrm{N}_{180}$ followed by USG-N $\mathrm{N}_{160}$ and $\mathrm{PU}-\mathrm{N}_{180}(70.55 \mathrm{~cm})$ and the lowest plant height $(58.83 \mathrm{~cm})$ was found from control (Figure 1). It was observed that the plant growth in relation to plant height was higher in USG treated plots than that in PU. This might be due to uninterrupted and continuous long time supply of $\mathrm{N}$ using USG which favors higher $\mathrm{N}$ 
uptake by the crop. But at higher $\mathrm{N}$ levels, decreasing trend in plant height might be due to higher lateral vegetative growth and over dose effect of nitrogen as well as imbalanced supply of nutrients. This result is nearly similar to the findings of Hala and Nadia (2009), where they showed that broccoli growth characters were significantly influenced by different mineral fertilizers.

\subsection{Plant growth in relation to number of leaves} The effect of different doses of $\mathrm{N}$ as PU and USG on the plant growth in relation to number of leaves was found significant from 20 DAT (Figure 2). It was observed that plant growth in relation to number of leaves was rapidly increased up to 50 DAT and then slowed down and ultimately reached the maximum value at 70 DAT. At head initiation stage (40-50 DAT) higher number of leaves was found under application of USG-N $\mathrm{N}_{160}$ and USG-N $\mathrm{N}_{180}$ which was statistically identical to PU-N 180 . Irrespective of treatment, variations in higher number of leaves was always observed under USG treated plots. At 70 DAT number of leaves showed a significant variation among the treatment combinations and the highest number (14.70) was recorded from the USG-N ${ }_{180}$ followed by USG-N $\mathrm{N}_{160}$ which was statistically identical with $\mathrm{PU}-\mathrm{N}_{200}$ but different from all other treatments. At harvesting, the highest number of leaves per plant (14.87) was recorded from USG-N $\mathrm{N}_{180}$ and it was also found highest in $P U-N_{180}$ (14.26). At the higher doses of $\mathrm{N}$, number of leaves decreased which may be due to the lateral growth with high availability of $\mathrm{N}$. The lowest number of leaves (12.53) was produced in control plot. However, higher number of leaves per plant was found under USG applied plots. This might be due to uniform and available supply of $\mathrm{N}$ as well as its higher use efficiency (Figure 10) by the crop. These results are in accordance with the findings of Ouda and Mahadeen (2008) in broccoli. Similar findings was reported by Hala and Nadia (2009), who showed that broccoli growth characters were significantly influenced by different mineral fertilizers and the maximum leaves per plant and leaves area were recorded by the plants with maximum $\mathrm{N}$ fertilizer.

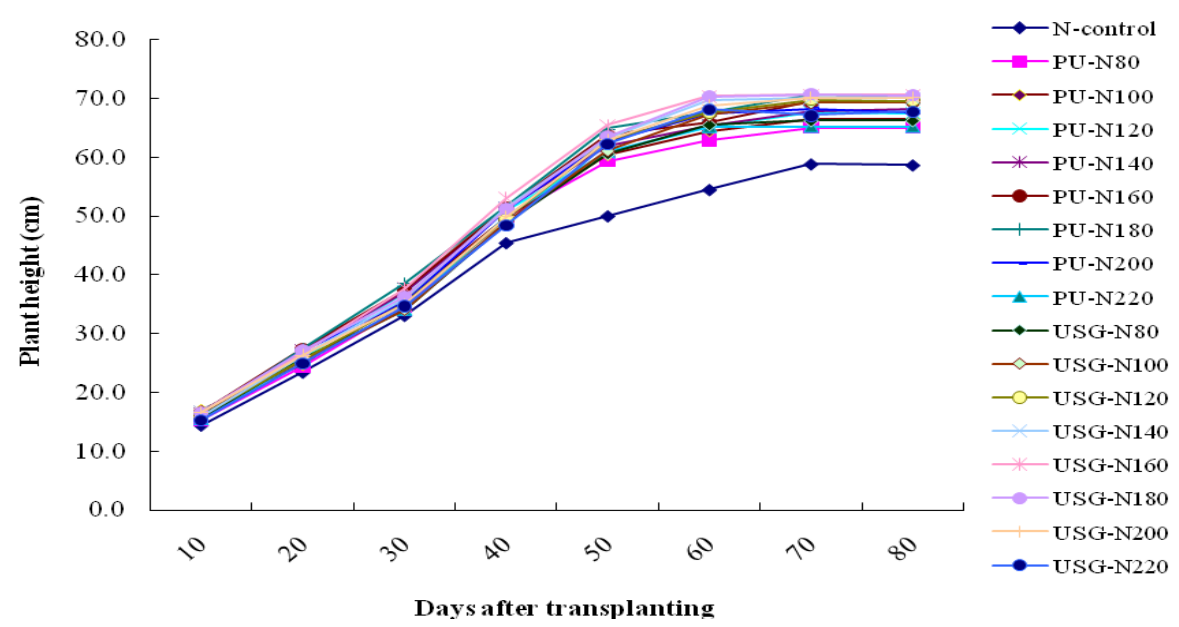

Figure 1. Growth pattern as affected by PU and USG in relation to plant height of broccoli at different DAT 


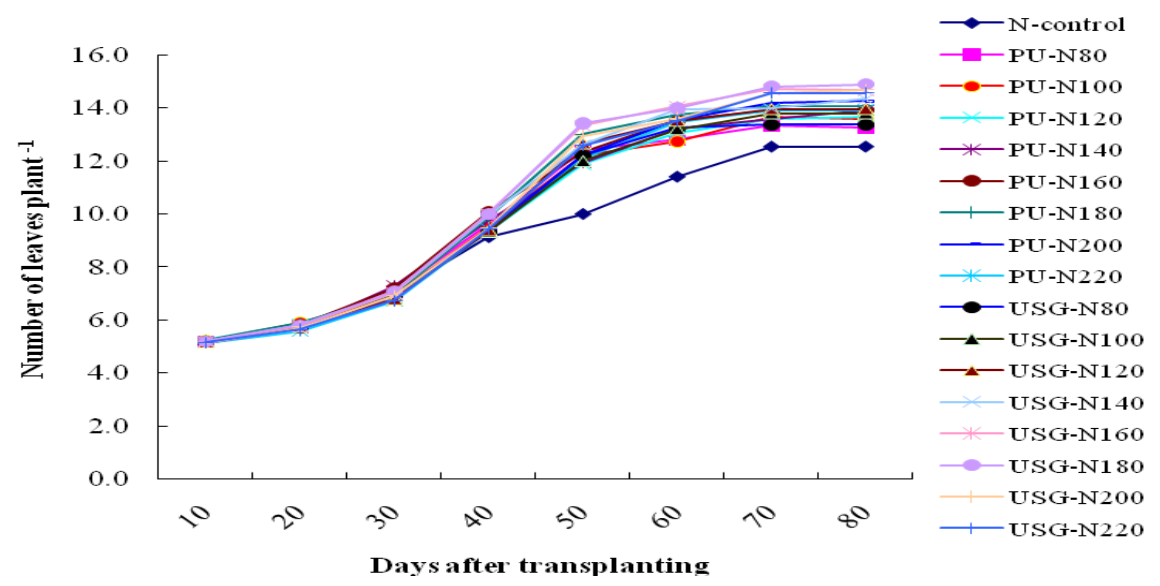

Figure 2. Growth pattern as affected by PU and USG in relation to number leaves of broccoli at different DAT.

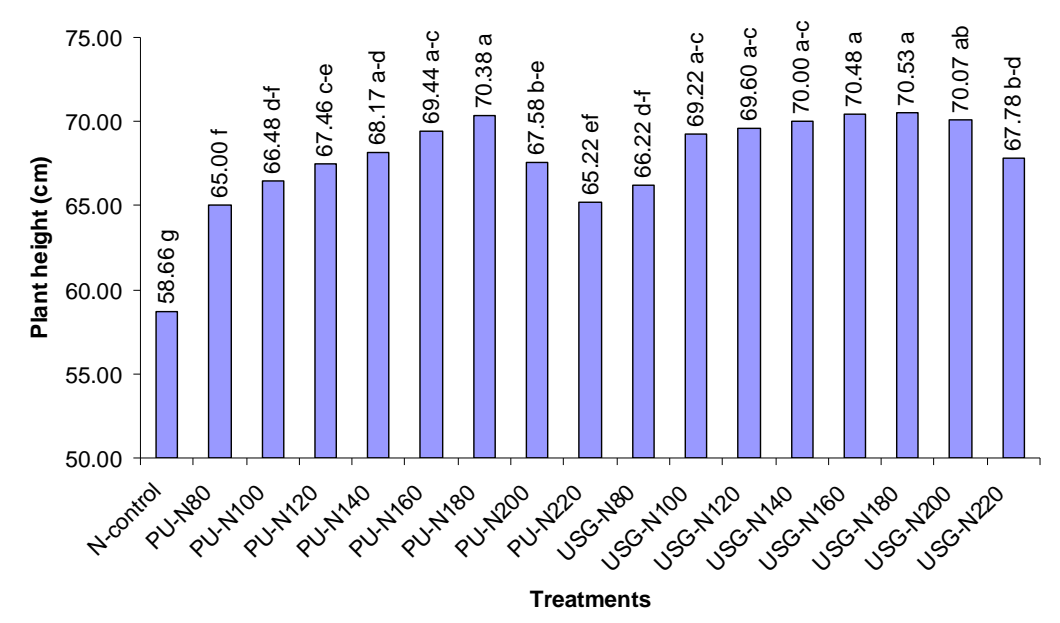

Figure 3. Effect of PU and USG on plant height of broccoli at harvesting (80 DAT)

\subsection{Plant height}

At 80 DAT plant height was significantly influenced by the treatment combination and increased with increasing rate of $\mathrm{N}$ for both the USG and PU upto180 $\mathrm{kg} \mathrm{N} \mathrm{ha}^{-1}$ and then it was decreased. The highest plant height $(70.53 \mathrm{~cm})$ was recorded from the treatment USG-N $\mathrm{N}_{180}$ followed by USG-N ${ }_{160}(70.48 \mathrm{~cm})$ and PU-N ${ }_{180}$ $(70.38 \mathrm{~cm})$ which was statistically identical with all the USG treatment except USG-N ${ }_{220}$, PU-N ${ }_{140}$ and PU-N $\mathrm{N}_{160}$ (Figure 3). Almost similar trend was observed in plant height from 20 to 70 DAT. This might be due to undisturbed supply of nutrient especially $\mathrm{N}$ and higher $\mathrm{N}$ uptake by the crop from USG. The prolonged supply of $\mathrm{N}$ by the USG may be the other cause for higher plant height in USG treated plants. But at higher level of $\mathrm{N}$ application decreasing trend shown was 
might be due to higher lateral vegetative growth and imbalanced supply of nutrients which caused reduced plant height. Therefore, it could be concluded that plant height was increased with increasing rate of nitrogenous fertilizers and higher growth and higher plant height was achieved from USG treated plots as compared to that of normal PU. This result is similar to the findings of Hala and Nadia (2009), where they showed that broccoli growth characters were significantly influenced by different mineral fertilizers and the highest plant height, branches and leaves number plant ${ }^{-1}$ were recorded in plants which were supplied by the fertilizer with maximum $\mathrm{N}$.

\subsection{Number of leaves per plant}

At harvesting (80 DAT) number of leaves plant ${ }^{-1}$ showed a significant variation among the treatment combinations and the highest number (14.87) was recorded from the $\mathrm{USG}_{-} \mathrm{N}_{180}$ followed by USG-N $\mathrm{N}_{160}$ which was statistically identical with PU-N $\mathrm{N}_{200}$ but different from all other treatment combinations (Figure 4). At the higher doses of $\mathrm{N}$, decreased number of leaves may be caused due to the lateral growth with high availability of $\mathrm{N}$. The lowest leaves plant ${ }^{-1}$ (12.53) was produced in control plot. But, higher number of leaves per plant was found under USG applied plots compare to PU. Among USG treated plots the highest number of leaves (14.87 plant $^{-1}$ ) was recorded from USG-N ${ }_{180}$ and it was found highest (14.26) in PU-N $\mathrm{N}_{180}$ in PU treated plots. This might be due to uniform and available supply of $\mathrm{N}$ as well as its higher uptake efficiency by the crop. These results are in accordance with the findings of Ouda and Mahadeen (2008) in broccoli. Similar findings was reported by Hala and Nadia (2009), who showed that broccoli growth characters were significantly influenced by different mineral fertilizers and the maximum leaves per plant and leaves area were recorded in plants with maximum $\mathrm{N}$ fertilizer.

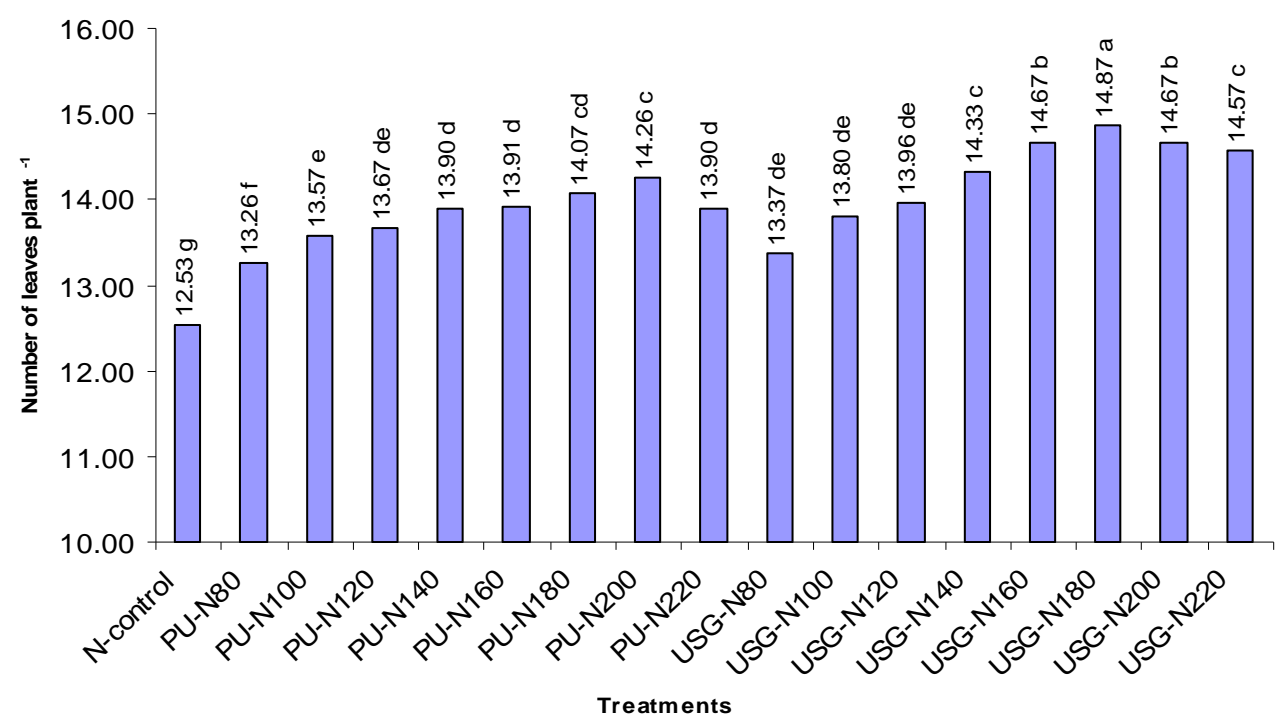

Figure 4. Effect of PU and USG on number of leaves per plant of broccoli at harvesting (80 DAT) 
Table 2. Effect of different levels of PU and USG on the days to head initiation of broccoli

\begin{tabular}{|c|c|c|c|c|}
\hline $\begin{array}{l}\text { Treatment } \\
\text { combinations }\end{array}$ & $\begin{array}{c}\text { Days to } 1^{\text {st }} \text { head } \\
\text { Initiation }\end{array}$ & $\begin{array}{l}\text { Days to } 50 \% \text { head } \\
\text { initiation }\end{array}$ & $\begin{array}{l}\text { Fresh shoot yield } \\
\qquad\left(\mathrm{g} \mathrm{plant}^{-1}\right)\end{array}$ & $\begin{array}{l}\text { Shoot dry weight } \\
\left(\text { g plant }^{-1}\right)\end{array}$ \\
\hline N-control & $50.33 \mathrm{a}$ & $53.33 \mathrm{ab}$ & $661.1 \mathrm{i}$ & $85.28 \mathrm{i}$ \\
\hline PU-N 80 & $49.33 \mathrm{a}-\mathrm{c}$ & $52.33 \mathrm{a}-\mathrm{d}$ & $838.9 \mathrm{~h}$ & $106.10 \mathrm{~h}$ \\
\hline PU-N 100 & 48.33 c-e & $52.33 \mathrm{a}-\mathrm{d}$ & $966.4 \mathrm{~g}$ & $124.70 \mathrm{~g}$ \\
\hline PU-N 120 & 48.67 b-e & $52.33 \mathrm{a}-\mathrm{d}$ & $1025.0 \mathrm{fg}$ & $132.30 \mathrm{fg}$ \\
\hline PU-N 140 & $48.00 \mathrm{de}$ & $51.33 \mathrm{~d}$ & $1122.0 \mathrm{de}$ & $144.80 \mathrm{de}$ \\
\hline PU-N 160 & $48.00 \mathrm{de}$ & $51.33 \mathrm{~d}$ & 1178.0 b-d & $152.20 \mathrm{~b}-\mathrm{d}$ \\
\hline PU-N 180 & $49.00 \mathrm{~b}-\mathrm{d}$ & $51.33 \mathrm{~d}$ & $1220.0 \mathrm{a}-\mathrm{c}$ & $157.40 \mathrm{a}-\mathrm{c}$ \\
\hline PU-N ${ }_{200}$ & $49.00 \mathrm{~b}-\mathrm{d}$ & $52.00 \mathrm{~b}-\mathrm{d}$ & 1195.0 b-d & $154.11 \mathrm{~b}-\mathrm{d}$ \\
\hline PU-N 220 & $49.67 \mathrm{ab}$ & $52.33 \mathrm{a}-\mathrm{d}$ & $1196.0 \mathrm{~b}-\mathrm{d}$ & $154.23 \mathrm{~b}-\mathrm{d}$ \\
\hline $\mathrm{USG}^{-\mathrm{N}_{80}}$ & $49.67 \mathrm{ab}$ & $53.00 \mathrm{a}-\mathrm{c}$ & $970.0 \mathrm{~g}$ & $125.13 \mathrm{~g}$ \\
\hline USG-N $_{100}$ & $49.33 \mathrm{a}-\mathrm{c}$ & 52.77 a-c & 1053.0 ef & 135.84 ef \\
\hline USG-N $_{120}$ & 48.33 c-e & $52.67 \mathrm{a}-\mathrm{d}$ & $1117.0 \mathrm{de}$ & $144.10 \mathrm{de}$ \\
\hline $\mathrm{USG} \mathrm{N}_{140}$ & $47.67 \mathrm{e}$ & $51.67 \mathrm{~cd}$ & $1163.0 \mathrm{~cd}$ & $150.10 \mathrm{~cd}$ \\
\hline USG-N 160 & $48.00 \mathrm{de}$ & $52.00 \mathrm{~b}-\mathrm{d}$ & 1244.0 a-c & $160.53 \mathrm{bc}$ \\
\hline USG-N ${ }_{180}$ & 48.33 c-e & $52.50 \mathrm{a}-\mathrm{d}$ & $1260.0 \mathrm{ab}$ & $162.11 \mathrm{ab}$ \\
\hline USG-N$_{200}$ & $49.00 \mathrm{~b}-\mathrm{d}$ & $53.33 \mathrm{ab}$ & $1287.0 \mathrm{a}$ & $166.00 \mathrm{a}$ \\
\hline $\mathrm{USG} \mathrm{N}_{220}$ & 49.33 a-c & $53.67 \mathrm{a}$ & 1194.0 b-d & $154.10 \mathrm{~b}-\mathrm{d}$ \\
\hline $\mathrm{CV} \%$ & 1.19 & 1.38 & 4.12 & 4.11 \\
\hline SE $( \pm 0.05)$ & 0.3367 & 0.4187 & 25.82 & 3.3207 \\
\hline
\end{tabular}

Means followed by uncommon letters are statistically different from each other at $5 \%$ level of provability by DMRT

\subsection{Days to $1^{\text {st }}$ and $50 \%$ head initiation}

Days to first head initiation was significantly affected by different forms and levels of urea nitrogen (Table 2). The highest days to $1^{\text {st }}$ head initiation (50.33 days) was required for control treatment which was statistically identical with PU-N ${ }_{80}$ and PU-N 220 and USG-N $\mathrm{N}_{80}$, USG-N $\mathrm{N}_{100}$ and USG- $\mathrm{N}_{220}$ and the minimum time (47.67 days) required for USG-N $\mathrm{N}_{140}$ treatment. The highest days to $50 \%$ head initiation (53.67days) was required for the treatment USG-N $\mathrm{N}_{220}$ which was followed by control and USG-N ${ }_{200}$ treatments. But the minimum days to $50 \%$ head initiation (51.33 days) was required for the treatment, PU-N ${ }_{140}, \mathrm{PU}-\mathrm{N}_{160}$ and $\mathrm{PU}-\mathrm{N}_{180}$. It revealed from the data that higher $\mathrm{N}$ level delayed head initiation as the higher vegetative growth was occurred but at zero $\mathrm{N}$ level delayed head initiation might be due to lack of optimum development and carbohydrate assimilation for maturity. The USG treated plots took more time to $50 \%$ head initiation as because of higher supply of $\mathrm{N}$, which induced higher vegetative growth as well as delayed head initiation. These findings were supported by the findings of Balyan et al. (1988) in cauliflower. Default (1988) also studied $\mathrm{N}$ and phosphorus requirements of greenhouse broccoli cv. Southern Comet and found that increasing $\mathrm{N}$ rates decreased the days to heading and harvest. Thakur et al. (1991) found that the increasing rate of $\mathrm{N}$ delayed head maturity of cauliflower.

\subsection{Fresh shoot yield and shoot dry weight}

Fresh shoot yield was significantly influenced by the different form and levels of urea nitrogen fertilizer (Table 2). The highest shoot weight (1287 $\mathrm{g} \mathrm{plant}^{-1}$ ) was obtained from the treatment USG-N $\mathrm{N}_{200}$ followed by USG- $\mathrm{N}_{180}$ and USG-N $\mathrm{N}_{160}$ and PU-N $\mathrm{N}_{180}$. The minimum shoot yield was recorded from control. Shoot weight was increased with increasing rate of $\mathrm{N}$ and the USG treated plots always gave the higher shoot weight in each $\mathrm{N}$ level as compared to PU. Similar trend 
was observed in shoot dry weight (Table 2). This result is in agreement with the findings of Zebarth et al. (1995) who reported that broccoli marketable yield increased curvilinearly with increasing rate of $\mathrm{N}$ fertilization for three planting as studied and total above ground dry matter increased linearly with increasing rate of $\mathrm{N}$ fertilization.

\subsection{Head length}

Significantly higher head length was recorded in PU treated plots than that of USG (Table 3) and the highest head length $(14.89 \mathrm{~cm})$ was recorded from PU-N $\mathrm{N}_{160}$ which was statistically highest over all other treatment combinations. The treatment combination PU-N $\mathrm{N}_{140}$ produced the second highest head length which was statistically identical to USG-N $\mathrm{N}_{160}$ treated plot. The minimum head length was found from the combination of PU-N 200 . Chao-Jiong et al. (2010) reported that the moderate application rate of $\mathrm{N}$ fertilizer (200-300 kg N ha $\left.{ }^{-1}\right)$ significantly increase the head size and maintain the storage life of broccoli.

\subsection{Head diameter}

Head diameter was also significantly influenced by the different forms and levels of urea nitrogen. The highest head diameter $(19.03 \mathrm{~cm})$ was observed from USG-N $\mathrm{N}_{160}$ that was significantly higher than all other treatment combinations (Table 3). The second highest head diameter $(18.26 \mathrm{~cm})$ was recorded from USG$\mathrm{N}_{180}$ which was statistically identical to USG$\mathrm{N}_{140}$, PU- $\mathrm{N}_{160}$ and the lowest head diameter (11.0 $\mathrm{cm})$ were found from control. The higher head diameter was achieved due to the continuous supply and availability of $\mathrm{N}$ from USG.

Table 3. Effect of different levels of PU and USG on the head weight, head length, head diameter and compactness coefficient (CC) of broccoli

\begin{tabular}{|c|c|c|c|c|}
\hline $\begin{array}{l}\text { Treatment } \\
\text { combinations }\end{array}$ & $\begin{array}{l}\text { Head weight } \\
\text { (g/plant) }\end{array}$ & $\begin{array}{l}\text { Head length } \\
(\mathrm{cm})\end{array}$ & $\begin{array}{l}\text { Head diameter } \\
(\mathrm{cm})\end{array}$ & $\begin{array}{l}\text { Compactness } \\
\text { coefficient (CC) }\end{array}$ \\
\hline N-control & $143.6 \mathrm{j}$ & $12.89 \mathrm{fg}$ & $11.11 \mathrm{j}$ & $12.93 \mathrm{hi}$ \\
\hline PU-N 80 & $202.7 \mathrm{i}$ & $13.67 \mathrm{~cd}$ & $14.33 \mathrm{i}$ & $14.15 \mathrm{gh}$ \\
\hline PU-N 100 & $224.5 \mathrm{hi}$ & $13.55 \mathrm{~d}$ & $15.94 \mathrm{~h}$ & $14.08 \mathrm{gh}$ \\
\hline PU-N 120 & $252.5 \mathrm{e}-\mathrm{g}$ & $13.56 \mathrm{~d}$ & $17.16 \mathrm{c}-\mathrm{h}$ & $14.71 \mathrm{fg}$ \\
\hline PU-N 140 & $272.1 \mathrm{c}-\mathrm{f}$ & $14.33 \mathrm{~b}$ & $17.17 \mathrm{c}-\mathrm{e}$ & $15.85 \mathrm{~d}-\mathrm{f}$ \\
\hline PU-N 160 & $274.8 \mathrm{c}-\mathrm{e}$ & $14.89 \mathrm{a}$ & $17.67 \mathrm{bc}$ & 15.55 ef \\
\hline PU-N 180 & $282.6 \mathrm{~cd}$ & $13.22 \mathrm{~d}-\mathrm{f}$ & $17.22 \mathrm{~cd}$ & $16.41 \mathrm{c}-\mathrm{e}$ \\
\hline PU-N 200 & $251.8 \mathrm{e}-\mathrm{g}$ & $12.22 \mathrm{i}$ & $17.05 \mathrm{de}$ & $14.77 \mathrm{fg}$ \\
\hline PU-N 220 & $242.3 \mathrm{gh}$ & $13.00 \mathrm{e}-\mathrm{g}$ & $15.94 \mathrm{gh}$ & $15.20 \mathrm{e}-\mathrm{g}$ \\
\hline USG-N ${ }_{80}$ & $247.7 \mathrm{f}-\mathrm{h}$ & $12.89 \mathrm{fg}$ & $15.72 \mathrm{~h}$ & $15.76 \mathrm{~d}-\mathrm{f}$ \\
\hline USG-N ${ }_{100}$ & $264.3 \mathrm{~d}-\mathrm{g}$ & $12.67 \mathrm{~g}-\mathrm{i}$ & $16.22 \mathrm{f}-\mathrm{h}$ & $16.29 \mathrm{c}-\mathrm{e}$ \\
\hline USG-N $_{120}$ & $281.0 \mathrm{~cd}$ & $12.55 \mathrm{~g}-\mathrm{i}$ & $16.55 \mathrm{e}-\mathrm{g}$ & $16.98 \mathrm{bc}$ \\
\hline $\mathrm{USG} \mathrm{N}_{140}$ & $312.1 \mathrm{~b}$ & $13.45 \mathrm{de}$ & $18.00 \mathrm{~b}$ & $17.33 \mathrm{~b}-\mathrm{d}$ \\
\hline USG-N ${ }_{160}$ & $347.2 \mathrm{a}$ & $14.11 \mathrm{bc}$ & $19.33 \mathrm{a}$ & $17.96 \mathrm{a}$ \\
\hline USG-N ${ }_{180}$ & $339.7 \mathrm{a}$ & $13.22 \mathrm{~d}-\mathrm{f}$ & $18.16 \mathrm{~b}$ & $18.71 \mathrm{a}$ \\
\hline USG-N ${ }_{200}$ & $293.6 \mathrm{bc}$ & $13.00 \mathrm{e}-\mathrm{g}$ & $16.56 \mathrm{e}-\mathrm{g}$ & $17.73 \mathrm{~b}$ \\
\hline $\mathrm{USG} \mathrm{N}_{220}$ & $271.6 \mathrm{c}-\mathrm{f}$ & $12.33 \mathrm{hi}$ & $16.61 \mathrm{~d}-\mathrm{f}$ & $16.35 \mathrm{c}-\mathrm{e}$ \\
\hline CV\% & 5.34 & 2.06 & 2.09 & 4.20 \\
\hline $\mathrm{SE}( \pm 0.05)$ & 7.955 & 0.1571 & 0.1949 & 0.3674 \\
\hline
\end{tabular}

Means followed by uncommon letters are statistically different from each other at $5 \%$ level of provability by DMRT 
This finding was in agreement with the findings of Yoldas et al. (2008) where he found that nitrogen rates significantly increased yield, average weight of main and lateral heads, and the diameter in broccoli compared to control. Similar results were reported by Chao-Jiong et al. (2010) in broccoli and showed that both the average weight and diameter of main head were significantly increased with the increase of nitrogen fertilization. They also concluded that the moderate rate of $\mathrm{N}$ application $(200-300 \mathrm{~kg}$ $\mathrm{N}$ ha $^{-1}$ ) significantly increase the head size and maintain the storage life of broccoli.

\subsection{Compactness coefficient (CC) of broccoli head}

Compactness coefficient (CC) of broccoli head in relation to head weight and head diameter was significantly affected by the different levels of USG and PU. Higher compactness coefficient was found in USG over PU and the maximum CC (18.71) was obtained from USG-N ${ }_{180}$ followed by USG-N $\mathrm{N}_{160}$ (17.96) which was statistically identical with each other and minimum CC (12.93) was recorded in control treatment. It indicated that USG positively increased the crop quality of broccoli.

\subsection{Head yield}

Head weight was significantly affected by the different forms and levels of urea N. It was observed that the individual head weight was increased with increasing rate of $\mathrm{N}$ up to PU$\mathrm{N}_{180}$ and USG-N $\mathrm{N}_{160}$ and it was decreased with further increment of $\mathrm{N}$ rate (Table 3). The highest head weight (347.24 $\left.\mathrm{g} \mathrm{plant}^{-1}\right)$ was obtained from the treatment USG- $\mathrm{N}_{160}$ followed by USG-N ${ }_{180}$ (339.73 $\left.\mathrm{g} \mathrm{plant}^{-1}\right)$ which was statistically identical with each other. Among PU treated plots, the highest head weight $(281.02 \mathrm{~g}$ plant $^{-1}$ ) was recorded from PU-N 180 that was statistically similar to PU-N $\mathrm{N}_{160}$. Data showed that in maximum cases USG treated plots produced higher individual head weight as compared to that produced under PU.

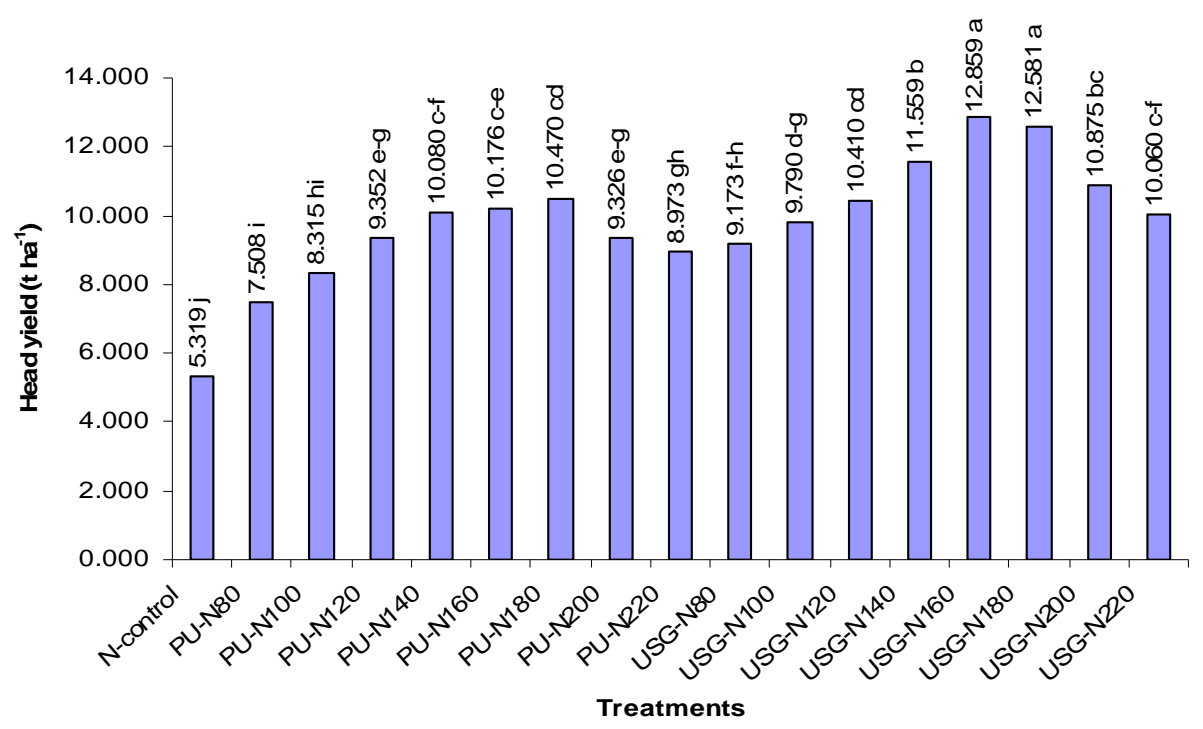

Figure 5. Effect of different levels of PU and USG on head yield $\left(\mathrm{t} \mathrm{ha}^{-1}\right)$ of broccoli 


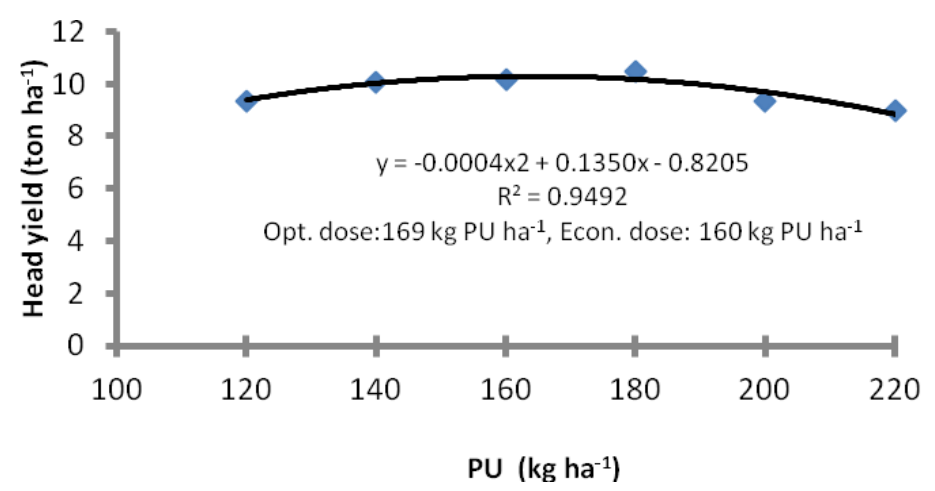

Figure 6a. Optimum and economic dose of prilled urea for maximum yield of broccoli

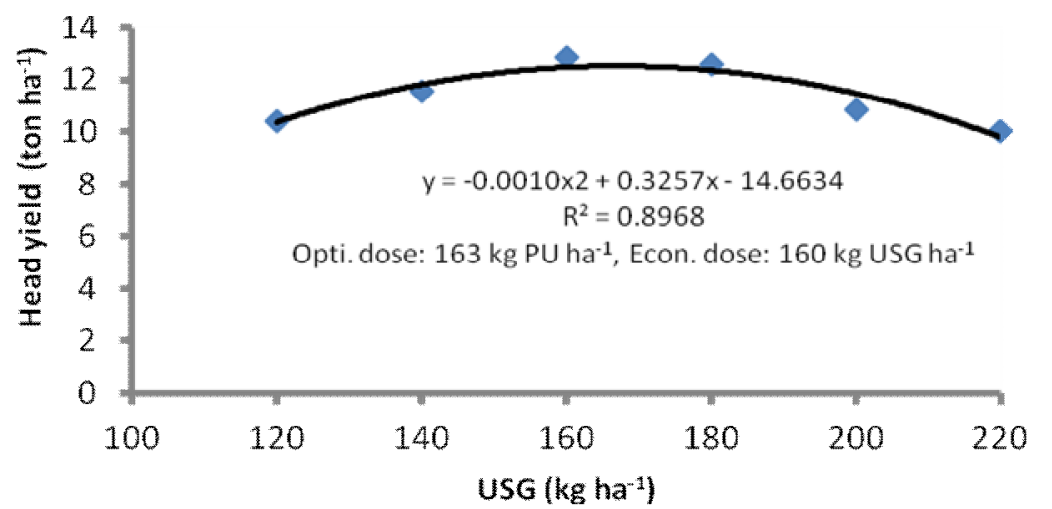

Figure 6b. Optimum and economic dose of USG for maximum yield of broccoli

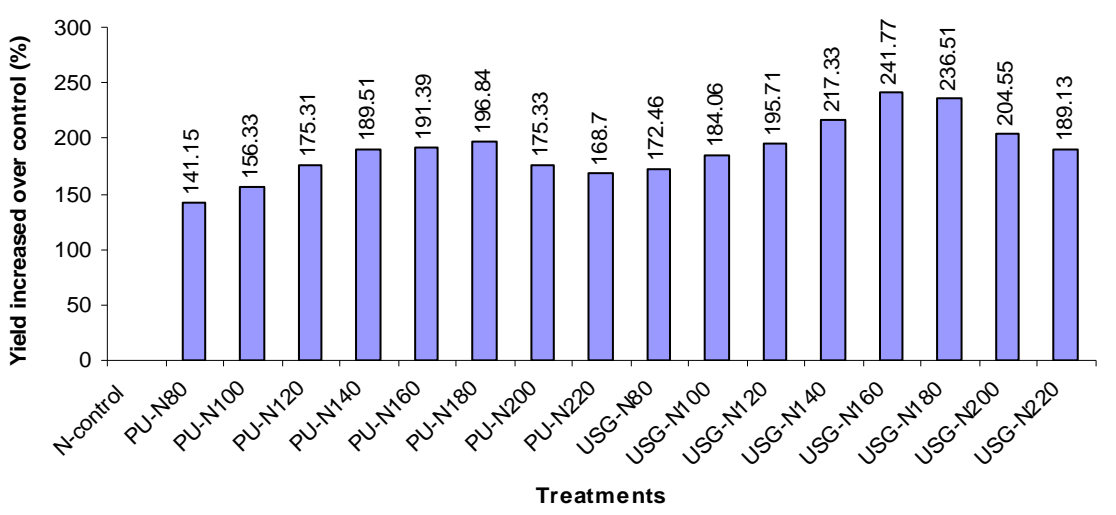

Figure 7. Yield increased over control (\%) as affected by different levels of PU and USG 


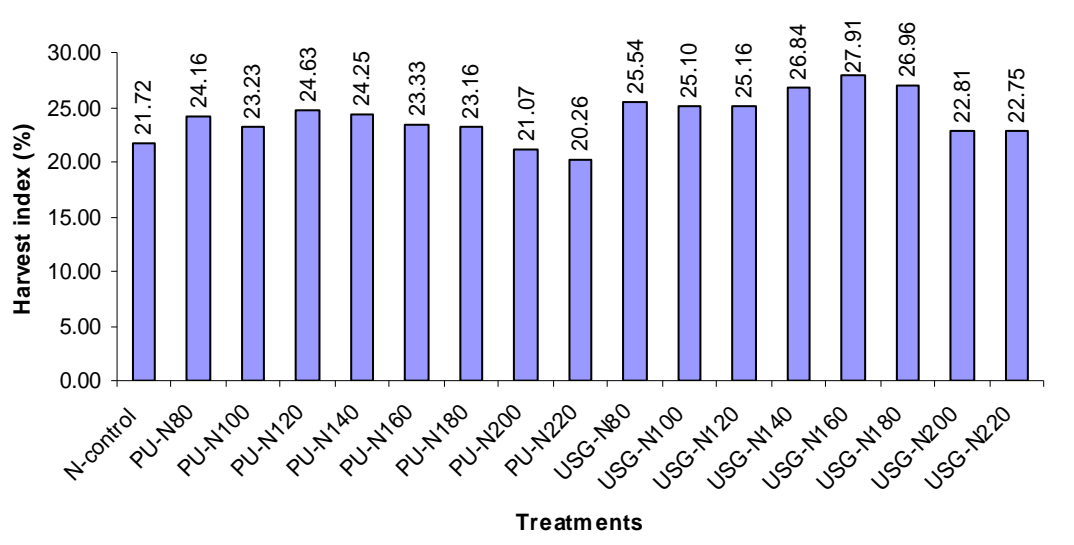

Figure 8. Harvest index (\%) of broccoli as affected by different levels of PU and USG

The minimum yield $\left(143.6 \mathrm{~g}\right.$ plant $\left.{ }^{-1}\right)$ was recorded from the control. Head yield in $\mathrm{t} \mathrm{ha}^{-1}$ has followed the same trend as was found in head weight in g plant $^{-1}$ (Figure 5). The highest head yield $\left(12.86 \mathrm{t} \mathrm{ha}^{-1}\right)$ was achieved from the treatment USG-N $\mathrm{N}_{160}$ followed by USG-N $\mathrm{N}_{180}$ $\left(12.58 \mathrm{t} \mathrm{ha}^{-1}\right)$ which were statistically identical. Among PU treated plots the highest head yield (10.47 $\mathrm{t} \mathrm{ha}^{-1}$ ) was recorded from PU-N $\mathrm{N}_{180}$, which was similar to USG-N $\mathrm{N}_{120}$ but significantly lower than that of the treatment USG-N $\mathrm{N}_{200}$. The minimum head yield was recorded from control. From quadratic regression equation according to FRG (2012) optimum and economic doses for USG and PU were obtained as 163 and $160 \mathrm{~kg}$ USG ha ${ }^{-1}$ and 169 and $160 \mathrm{~kg} \mathrm{PU} \mathrm{ha}{ }^{-1}$ for broccoli production (Figure $6 \mathrm{a}$ and $6 \mathrm{~b}$ ).

The highest yield increased over control $(241.77 \%)$ was found from USG-N $\mathrm{N}_{160}$ whereas it was only $196.84 \%$ from PU-N 180 (Figure 7) which indicates the higher availability and efficient use of $\mathrm{N}$ under USG application. Similarly, the highest harvest index $(27.9 \%)$ was found from USG-N $\mathrm{N}_{160}$ in comparison to the harvest index of $23.33 \%$ from PU-N $\mathrm{N}_{160}$ that was the maximum value in PU treated plots (Figure 8). From It was observed that head yield and harvest index was increased with increasing rate of nitrogenous fertilizers up to a certain level and followed a curvilinear fashion in both for PU and USG treatments (Figure $7 \&$ 8). Results showed that overall performance of USG was better than that of PU. The low yield harvested from the control treatment is due to the insufficient supply of $\mathrm{N}$, which leads to limitation of carbon assimilation and reduction in plant productivity (Shangguan et al., 2000, Lawlor, 2002). The higher yield obtained from USG might be due to decreased $\mathrm{N}$ emissions and volatilization loss from the deep placed $\mathrm{N}$ as USG which might have ensured continuous and uniform supply of available $\mathrm{N}$ for better crop uptake by the broccoli plant throughout the growing period. The possible reason is that as USG placed at deeper zone where limited number of nitrifying bacteria present at the premise of the USG and convert a limited portion of urea to $\mathrm{NO}_{3}{ }^{-}$which is utilized by the plant efficiently and reduced $\mathrm{N}$ loss. Mukherjee (1986) reported that the USG with deep placement provided a zone of concentrated urea solution where the denitrifying bacteria cannot enter and therefore $\mathrm{N}$ is left at the root zone for uptake by the plants. This result was in agreement with the findings of Mohanthy et al. (1999) and Yoldas et al. (2008). Greenwood et al. (1980) optimize the $\mathrm{N}$ dose to receive the maximum broccoli yield with the recommended doses from 175-252 $\mathrm{kg} \mathrm{N} \mathrm{ha}^{-1}$. Similar findings were reported by Hussain et al. (2010) with 
cauliflower, Rahman et al. (2004) in potato and Khalil et al. (2009) in wheat.

\subsection{Number of lateral head}

The residual effect of different forms and levels of urea on lateral head yield of broccoli was found significant (Table 5). The highest number of lateral head (7.43 plant $\left.^{-1}\right)$ was recorded from USG- $\mathrm{N}_{140}$ followed by USG-N $\mathrm{N}_{140}$ and USG-N $\mathrm{N}_{160}$, which were statistically identical with each other. It was clearly observed that the higher number of lateral head was formed with the application of USG as compared to PU. The lowest number was obtained from control. Better growth of lateral head may contribute significantly to the total yield of broccoli. Slow nutrient releasing fertilizers can play positive role in lateral head yield of broccoli. It was reported that nitrogen rates significantly increased yield, average weight of main and lateral heads, and the diameter in broccoli compared to control (Yoldas et al., 2008; ChaoJiong, 2010; Ouda and Mahadeen, 2008; Moniruzzaman et al., 2007 and Hussain, 2004). Hussain (2004) also reported that number of lateral head plant $^{-1}$ was decreased with the increasing level of $\mathrm{N}$ from $60 \mathrm{~kg} \mathrm{ha}^{-1}$ and the highest number (4.053 plant $^{-1}$ ) was recorded from $60 \mathrm{~kg} \mathrm{~N} \mathrm{ha}^{-1}$ where the highest level of $\mathrm{N}$ $\left(180 \mathrm{~kg} \mathrm{ha}^{-1}\right)$ produced only 3.52 lateral heads plant $^{-1}$ which supported the present findings.

\subsection{Lateral head yield}

The residual effect of different form and levels of $\mathrm{N}$ fertilizer significantly influenced lateral head weight $\left(\mathrm{g}_{\text {plant }}{ }^{-1}\right)$ and it was increased with the increasing levels of $\mathrm{N}$ (Table 5).

Table 5. Effect of different levels of PU and USG on the lateral head yield of broccoli

\begin{tabular}{|c|c|c|c|}
\hline $\begin{array}{l}\text { Treatment } \\
\text { combinations }\end{array}$ & $\begin{array}{c}\text { Number of lateral head } \\
\text { plant }^{-1}\end{array}$ & $\begin{array}{l}\text { Lateral head weight } \\
\qquad\left(\mathrm{g}^{\text {g plant }}{ }^{-1}\right)\end{array}$ & $\begin{array}{l}\text { Lateral head yield } \\
\qquad\left(\mathrm{t} \mathrm{ha}^{-1}\right)\end{array}$ \\
\hline $\mathrm{N}$-control & $2.60 \mathrm{~h}$ & $49.33 \mathrm{k}$ & $1.827 \mathrm{o}$ \\
\hline PU-N 80 & $5.73 \mathrm{f}$ & $58.33 \mathrm{k}$ & $2.160 \mathrm{n}$ \\
\hline PU-N 100 & $5.93 \mathrm{ef}$ & $72.22 \mathrm{j}$ & $2.675 \mathrm{~m}$ \\
\hline PU-N 120 & $5.93 \mathrm{ef}$ & $78.00 \mathrm{ij}$ & 2.8891 \\
\hline PU-N 140 & $6.63 \mathrm{~b}-\mathrm{d}$ & $101.7 \mathrm{~h}$ & $3.765 \mathrm{j}$ \\
\hline PU-N ${ }_{160}$ & $6.00 \mathrm{ef}$ & $108.3 \mathrm{gh}$ & $4.012 \mathrm{i}$ \\
\hline PU-N 180 & $6.43 \mathrm{c}-\mathrm{e}$ & $143.3 \mathrm{e}$ & $5.309 \mathrm{f}$ \\
\hline PU-N ${ }_{200}$ & $6.40 \mathrm{c}-\mathrm{e}$ & $183.3 \mathrm{c}$ & $6.790 \mathrm{c}$ \\
\hline PU-N 220 & $6.50 \mathrm{c}-\mathrm{e}$ & $150.0 \mathrm{e}$ & $5.556 \mathrm{e}$ \\
\hline USG-N 80 & $6.53 \mathrm{~b}-\mathrm{e}$ & $86.67 \mathrm{i}$ & $3.210 \mathrm{k}$ \\
\hline USG-N$_{100}$ & $6.70 \mathrm{~b}-\mathrm{d}$ & $119.0 \mathrm{f}$ & $4.407 \mathrm{~g}$ \\
\hline USG-N$_{120}$ & $7.13 \mathrm{ab}$ & $115.0 \mathrm{fg}$ & $4.259 \mathrm{~h}$ \\
\hline USG-N $_{140}$ & $7.43 \mathrm{a}$ & $168.3 \mathrm{~d}$ & $5.741 \mathrm{~d}$ \\
\hline $\mathrm{USG} \mathrm{N}_{160}$ & $6.93 \mathrm{a}-\mathrm{c}$ & $193.3 \mathrm{ab}$ & $7.160 \mathrm{~b}$ \\
\hline USG-N$_{180}$ & $6.80 \mathrm{~b}-\mathrm{d}$ & $196.7 \mathrm{a}$ & $7.284 \mathrm{~b}$ \\
\hline USG-N$_{200}$ & $6.30 \mathrm{~d}-\mathrm{f}$ & $200.7 \mathrm{a}$ & $7.432 \mathrm{a}$ \\
\hline USG-N$_{220}$ & $6.67 \mathrm{~b}-\mathrm{d}$ & $186.7 \mathrm{bc}$ & $6.914 \mathrm{c}$ \\
\hline CV\% & 5.29 & 4.46 & 1.70 \\
\hline $\mathrm{SE}( \pm 0.05)$ & 0.1871 & 3.238 & 0.0447 \\
\hline
\end{tabular}

Means followed by uncommon letters are statistically different from each other at $5 \%$ level of provability by DMRT 


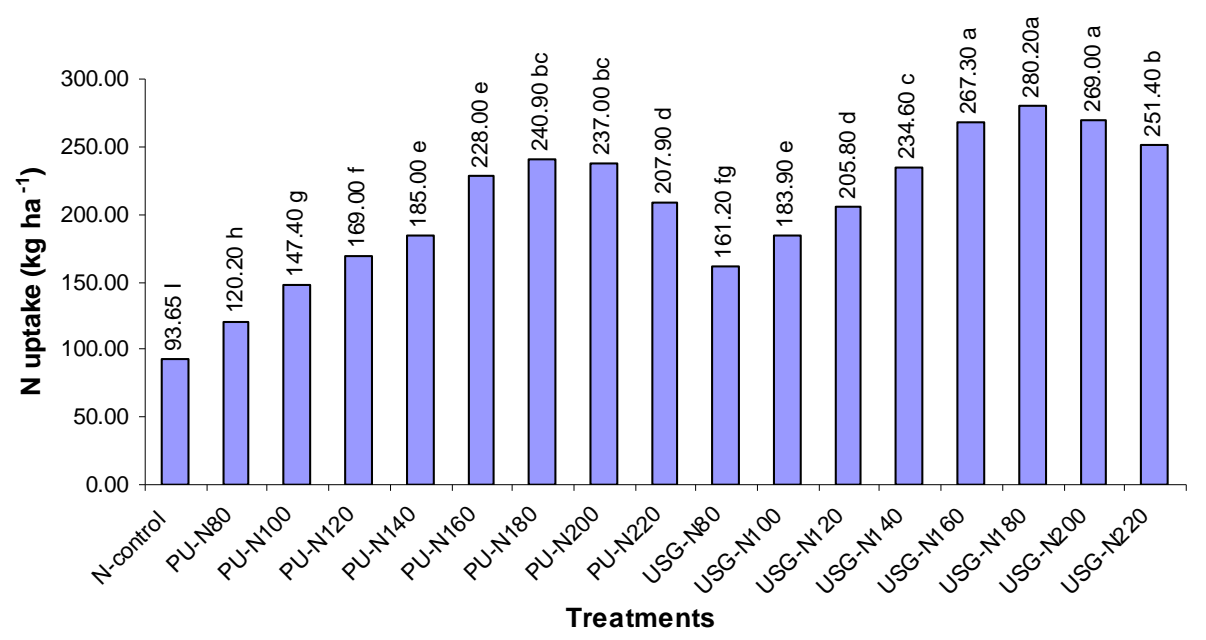

Figure 9. Effect of different levels of PU and USG on $\mathrm{N}$ uptake by the broccoli plant

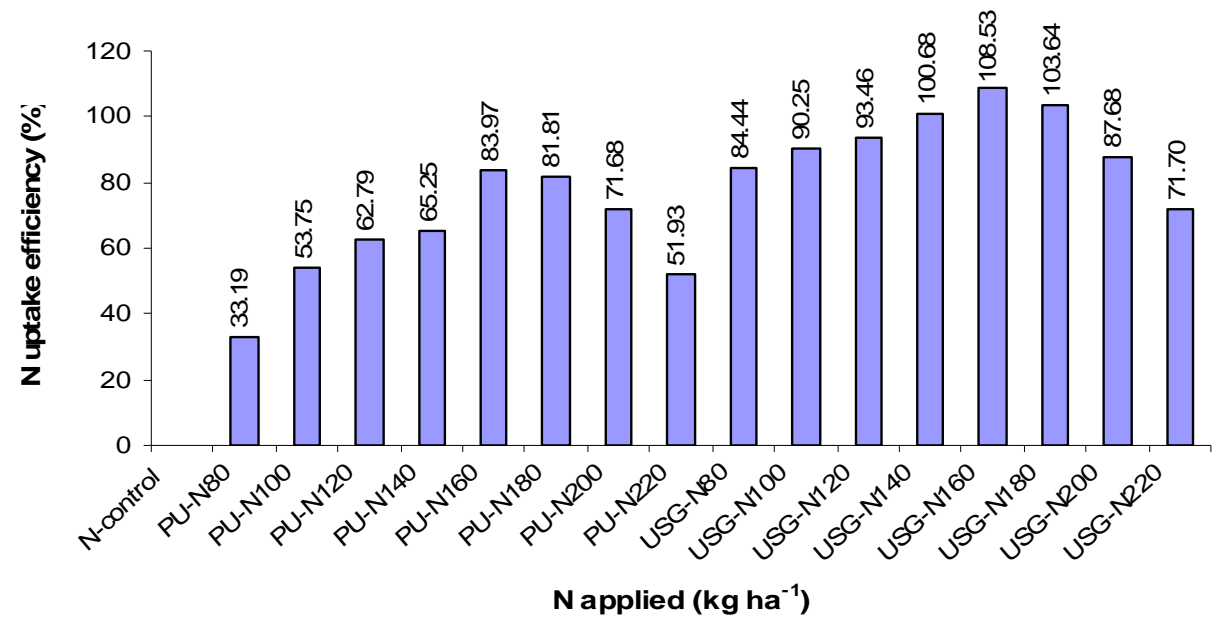

Figure 10. Effect of different levels of PU and USG on N use efficiency of broccoli plant

The higher lateral head weight was observed in case of USG as compared to PU. The maximum lateral head weight $\left(200.7 \mathrm{~g} \mathrm{plant}^{-1}\right)$ was recorded from USG-N $\mathrm{N}_{200}$ followed by USG-N $\mathrm{N}_{180}$, which were statistically identical with each other. The lowest lateral head weight (49.33 $\left.\mathrm{g} \mathrm{plant}^{-1}\right)$ was obtained from control. Similarly, lateral head yield $\left(\mathrm{t} \mathrm{ha}^{-1}\right)$ was significantly affected by the different forms and levels of $\mathrm{N}$ and more or less; it was increased with the increasing levels of $\mathrm{N}$ (Table 5). The highest lateral head yield $(7.432 \mathrm{t}$ $\mathrm{ha}^{-1}$ ) was recorded from the treatment combination USG-N $\mathrm{N}_{200}$ that was significantly higher from all other treatments. The second highest lateral head yield $\left(7.284 \mathrm{t} \mathrm{ha}^{-1}\right)$ was recorded from USG-N $\mathrm{N}_{180}$ which was statistically identical with USG-N ${ }_{160}$. Data represent that the higher lateral head yield was produced with 
higher $\mathrm{N}$ levels as the form of USG. The lowest lateral head yield $\left(1.827 \mathrm{t} \mathrm{ha}^{-1}\right)$ was obtained from control plot. This higher lateral head production may be due to the effect of prolonged supply of $\mathrm{N}$ by the deep placed USG as the residual effect. Yoldas et al. (2008) who found that $\mathrm{N}$ rates significantly increased yield, average weight of main and lateral heads, and the diameter in broccoli compared to control. Similar results were reported by Chao-Jiong (2010) who showed that both the average weight and diameter of main head and lateral heads of broccoli were significantly increased with the increase of nitrogen fertilization from 200-300 $\mathrm{kg} \mathrm{N} \mathrm{ha}^{-1}$. Hussain (2004) reported that lateral head yield of broccoli was significantly influenced by different $\mathrm{N}$ level and the highest lateral head yield $\left(5.553 \mathrm{t} \mathrm{ha}^{-1}\right)$ was obtained from the highest $\mathrm{N}$ level of $180 \mathrm{~kg} \mathrm{ha}^{-1}$.

\subsection{Nitrogen uptake and uptake efficiency}

The effect of different forms and levels of urea nitrogen on $\mathrm{N}$ uptake and its uptake efficiency is presented in Figure 9 and 10. Nitrogen uptake was increased significantly with increasing levels of $\mathrm{N}$ which followed a curvilinear fashion and the highest $\mathrm{N}$ uptake $\left(280.2 \mathrm{~kg} \mathrm{ha}^{-1}\right)$ was recorded from USG- $\mathrm{N}_{180}$ which was statistically identical with USG-N $\mathrm{N}_{200}$ and USG-N $\mathrm{N}_{160}$. The highest $\mathrm{N}$ uptake from PU (240.9 $\left.\mathrm{kg} \mathrm{ha}^{-1}\right)$ was recorded by the application of $180 \mathrm{~kg}$ prilled urea $\left(\mathrm{PU}-\mathrm{N}_{180}\right)$. The overall $\mathrm{N}$ uptake performance was higher in USG treated plots than that of PU (Figure 9). This might be due to continuous supply and higher availability of $\mathrm{N}$ that induced better crop growth as well as higher dry matter production, $\mathrm{N}$ content and minimum loss of $\mathrm{N}$ due to deep placement of USG that have lead to higher $\mathrm{N}$ harvest and greater fertilizer-N recovery than that of PU. The possible reason for higher $\mathrm{N}$ uptake is that as USG placed at deeper zone the limited number of nitrifying bacteria present at the premise of the USG and converts a limited portion of urea to $\mathrm{NO}_{3}{ }^{-}$and takes more time to convert whole USG as compared to PU which may be utilized by the plant throughout the whole growing period. Mukherjee (1986) explained this phenomenon as the USG with deep placement provided a zone of concentrated urea solution where the denitrifying bacteria cannot enter and therefore $\mathrm{N}$ is left at the root zone for uptake by the plants. This result is in agreement with Khalil et al. (2011) who reported that deeper placements of USGs $(5.0-7.5 \mathrm{~cm})$ resulted in greater fertilizer-N recovery in the crop (70.5$78.0 \%$ ) compared to the use of prills $(56.6 \%)$.

From Figure 10, it was found that the $\mathrm{N}$ uptake efficiency was increased with increasing levels of $\mathrm{N}$ up to PU-N $\mathrm{N}_{160}(83.969 \%)$ and $\mathrm{USG} \mathrm{N}_{160}$ (108.531\%) and then it was decreased. Rashid et al. (1996) reported that $\mathrm{N}$ from USG was more efficiently used than that of PU and they stated that deep placement of USG is an effective means of increasing $\mathrm{N}$ use efficiency of rice as compared to the traditional split application of PU. Zebarth et al. (1995) also stated that apparent fertilizer-N recovery in the above ground portion of the plant decreased linearly from between 46 and $93 \%$ at a $\mathrm{N}$ rate of $125 \mathrm{~kg}$ $\mathrm{ha}^{-1}$ to between 20 and $4 \%$ at an $\mathrm{N}$ rate of $625 \mathrm{~kg}$ $\mathrm{ha}^{-1}$. Moreover, apparent fertilizer-N recovery in the harvested portion of the plant decreased linearly from between 14 and $25 \%$ at an $\mathrm{N}$ rate of $125 \mathrm{~kg} \mathrm{ha}^{-1}$ to between 8 and $14 \%$ at an $\mathrm{N}$ rate of $625 \mathrm{~kg} \mathrm{ha}^{-1}$. Most studies have shown that the $\mathrm{N}$ use efficiency (NUE) of broccoli decreased with increasing amount of $\mathrm{N}$ application (Mukherjee, 1986; Zebarth et al., 1995; Tremblay \& Beaudet, 2006 and Khalil et al., 2011).

\subsection{Economic analyses and evaluation}

A partial budget analysis was made and presented in Table 6. It was found that the maximum gross return (Tk.385770.00) was obtained from USG-N $\mathrm{N}_{160}$ followed by USG-N $\mathrm{N}_{180}$ with the higher gross margin of Tk.374255.20 and TK. 365063.10, respectively. Similarly, the highest marginal benefit cost ratio (MBCR) (19.64) was found from USG-N $\mathrm{N}_{160}$ followed by USG-N $\mathrm{N}_{180}$, but the highest level of PU treatment $\left(\mathrm{PU}-\mathrm{N}_{180)}\right.$ showed the maximum $\mathrm{MBCR}$ of 10.38 , which was lower than that of the USG treated plots. 
Table 6. Partial budget analysis of broccoli production as influenced by different levels of PU and USG

\begin{tabular}{|c|c|c|c|c|c|c|}
\hline $\begin{array}{l}\text { Treatment } \\
\text { combination }\end{array}$ & $\begin{array}{c}\text { Yield } \\
\left(\mathrm{t} \mathrm{ha}^{-1}\right)\end{array}$ & $\begin{array}{c}\text { Gross } \\
\text { return (Tk.) }\end{array}$ & $\begin{array}{c}\text { Total } \\
\text { variable cost } \\
\text { (Tk.) }\end{array}$ & $\begin{array}{c}\text { Gross margin } \\
\text { (Tk.) }\end{array}$ & $\begin{array}{c}\text { Added } \\
\text { return }(\mathrm{Tk} .)\end{array}$ & $\begin{array}{c}\text { MBCR* } \\
\text { Over } \\
\text { control }\end{array}$ \\
\hline N-control & 5.319 & 159570 & 0.00 & 159570.00 & - & - \\
\hline PU-N 80 & 7.508 & 225240 & 12267.60 & 212972.40 & 65670 & 5.35 \\
\hline PU-N ${ }_{100}$ & 8.315 & 249450 & 12788.40 & 236661.60 & 89880 & 7.03 \\
\hline PU-N 120 & 9.352 & 280560 & 13309.20 & 267250.80 & 120990 & 9.09 \\
\hline PU-N 140 & 10.080 & 302400 & 13830.00 & 288570.00 & 142830 & 10.33 \\
\hline PU-N ${ }_{160}$ & 10.176 & 305400 & 14350.80 & 290929.20 & 145710 & 10.15 \\
\hline PU-N 180 & 10.466 & 313980 & 14871.60 & 299108.40 & 154410 & 10.38 \\
\hline PU-N 200 & 9.326 & 279780 & 15392.40 & 264387.60 & 120210 & 7.81 \\
\hline PU-N 220 & 8.973 & 269190 & 16913.20 & 252276.80 & 109620 & 6.48 \\
\hline USG-N $_{80}$ & 9.173 & 275190 & 7184.80 & 268005.20 & 115620 & 16.09 \\
\hline USG-N $_{100}$ & 9.790 & 293700 & 8112.50 & 285587.50 & 134130 & 16.53 \\
\hline USG-N $_{120}$ & 10.408 & 312240 & 9267.20 & 302972.80 & 152670 & 16.47 \\
\hline USG-N $_{140}$ & 11.559 & 346770 & 9969.70 & 336800.30 & 187200 & 18.78 \\
\hline USG-N $_{160}$ & 12.859 & 385770 & 11514.80 & 374255.20 & 226200 & 19.64 \\
\hline USG-N $_{180}$ & 12.581 & 377430 & 12366.90 & 365063.10 & 217860 & 17.62 \\
\hline USG-N 200 & 10.875 & 326400 & 14297.20 & 311952.80 & 166680 & 11.66 \\
\hline USG-N 220 & 10.060 & 301800 & 15689.30 & 286110.70 & 142230 & 9.07 \\
\hline
\end{tabular}

Material cost: $\mathrm{PU}=\mathrm{Tk} .12 / \mathrm{kg}$; USG= Tk.12.50/kg. Placement cost $\left(\right.$ labor $\left.\mathbf{h a}^{-1}\right)$ : Prilled urea:56.58 labor ha ${ }^{-1}$ (2 times) common for all doses; USG: 27.86 labour for $80 \mathrm{~kg}, 30.00$ labor for $100 \mathrm{~kg}, 32.29$ labor for $120 \mathrm{~kg}, 34.29$ labor for $140 \mathrm{~kg}, 39.86$ labor for $160 \mathrm{~kg}, 41.58$ labor for $180 \mathrm{~kg}, 49.29$ labor for $200 \mathrm{~kg}$ and 54.01 labour for $220 \mathrm{~kg}$ USG. Labor= Tk.180/diam; Output cost: Broccoli= Tk. 30/kg; *Marginal benefit-cost ratio.

This indicated that the performance of USG is superior in terms of yield, gross return, gross margin and MBCR over control. Similar results were found from the study of Talukder et al. (2004) who reported that the efficiency of USG was found to be positive on the yield of tomato and $20 \% \mathrm{~N}$ might be saved using USG compared to PU. The economic analysis also showed that the use of urea super granule was economically viable to cultivate the tomato. Sarker et al. (2012) showed that USG was more effective over PU, and $\mathrm{N}$ loss was also minimum than that of PU where 10-20\% N fertilizer could be saved by using USG instead of traditional PU. They also reported that all the rate of $\mathrm{N}$ as USG showed better performance than that of normal PU for cabbage yield and found economically viable. This result also corroborates with that of the findings of Talukder et al. (2004) and Rahman et al. (2004).

Gross return and variable costs were calculated considering the following price rate of the materials as: Input cost: PU @ Tk. $12.00 \mathrm{~kg}^{-1}$, USG @ Tk. 12.30 kg-1, TSP @ Tk. $22 \mathrm{~kg}^{-1}$, MoP @ Tk. $20 \mathrm{~kg}^{-1}$, Gypsum @ Tk. $7 \mathrm{~kg}^{-1}$, zinc oxide and sodium monohydrate @ Tk. $180 \mathrm{~kg}^{-1}$, Borax @ Tk. $15 \mathrm{~kg}^{-1}$, Cow dung @ Tk. 1500 ton $^{-1}$, Poultry manure@Tk. 2000 ton $^{-1}$, Mustard oil cake@ Tk. $28 \mathrm{~kg}^{-1}$ (according to market rate during the year 2010-2011). Fertilizer application and placement cost were considered as a variable cost, which was estimated through labour requirement $\mathrm{ha}^{-1}$ according to treatments. These are: 56.58 labor ha $^{-1}$ (2 times application) common for all the PU treatment; 27.86 labour 
for $80 \mathrm{~kg}$; 30 labor for $100 \mathrm{~kg}, 2.29$ labor for 120 $\mathrm{kg}, 34.29$ labor for $140 \mathrm{~kg}, 39.86$ labor for 160 $\mathrm{kg}, 41.58$ labor for $180 \mathrm{~kg}, 49.29$ labor for 200 $\mathrm{kg}$ and 54.01 labour for $220 \mathrm{~kg}$ USG treatment per hectare. Labor cost $=$ Tk.180 diam ${ }^{-1}$. Output cost: Broccoli= @ Tk. $30 \mathrm{~kg}^{-1}$ (according to market rate during the year 2010-2011).

\section{Conclusions}

Results obtained from the above discussion suggested that the crop growth in relation to plant height and number of leaves was increased significantly followed by a sigmoid curve by the application of different levels of USG and PU and USG produced higher crop growth than PU. Plant height and number of leaves were also increased curvilinierly with increasing rate of $\mathrm{N}$ fertilizer. Head yield was increased with the increasing levels of $\mathrm{N}$ and the highest head yield was obtained from USG-N $\mathrm{N}_{160}$ which was significantly higher than that of PU. Similarly higher rate of $\mathrm{N}$ application produced higher lateral head yield but decreased in number. Overall, the performance of USG is found superior to PU in terms of yield, gross return, gross margin and MBCR over control and the highest MBCR was recorded from USG-N $\mathrm{N}_{160}$. Therefore, USG @ 160 kg N ha ${ }^{-1}$ and PU @ 180 $\mathrm{kg} \mathrm{N} \mathrm{ha}{ }^{-1}$ along with other recommended fertilizers could be suggested for broccoli production in terms of yield and economics. From quadratic equation USG @ 163 and $160 \mathrm{~kg}$ N ha ${ }^{-1}$ and PU@ 169 and 160 kg N ha ${ }^{-1}$ along with other recommended fertilizers could be suggested as optimum as economic doses for broccoli production in Silty Clay Loam Soil of Madhupur Tract.

\section{References}

Balyan, D. S., Dhankar, B. S., Ruhal, D. S. and Singh, K. P., 1988. Growth and yield of cauliflower variety Snowball-16 as influenced by nitrogen, phosphorus and zinc. Haryana Journal of Horticultural Science, 17: 247-254.
BARC, 2005. Fertilizer Recommendation Guide. Bangladesh Agricultural Research Council, Soils Pub. No. 45. 237-238 pp.

Brammer, H. 1980. Plough pan and tillage problems in Bangladesh. BARC $\mathrm{S} \& \mathrm{I}$ Pub. No. 5: 5.

Chao-Jiong Xu, Rong-Fang Guo, Hui-Zhuan Yan, Jing Yuan, Bo Sun, Gao-Feng Yuan and Qiao-Mei Wang, 2010. Effect of nitrogen fertilization on ascorbic acid, glucoraphanin content and quinine reductase activity in broccoli floret and stem. Journal of Food, Agriculture \& Environment, 8 (1): 179-184.

FAO, 1988. Production year book. Food and Agricultural Organization. Rome, 157$158 \mathrm{pp}$.

Greenwood D. J., Cleaver T. J., Turner M. K., Hunt J., Niendorf K. B., Loquens S. M. H., 1980. Comparison of the effects of nitrogen fertilizer on the yield, nitrogen content and quality of 21 different vegetable and agricultural crops. Journal of Agricultural Science, 95:471-585.

Hala Kandil and Nadia Gad, 2009. Effects of inorganic and organic fertilizers on growth and production of broccoli (Brassica Oleracea L.). Factori şi Procese Pedogenetice din Zona Temperată S. Nouă,8: 61-69.

Haque, S.A., 2002. Urea super granule point placement on potato: A new concept, 1-6 pp. In Proceedings of the $17^{\text {th }}$ World Congress of Soil Science, Thailand. Symposium No. 14. 2030, 14-21.

Hussain, M. J., Ali, M. Y., Rahman, M. A., Helim Khan, M. A. and Rahman, M. M., 2003. Application of urea super granule (USG) in vegetable crops: a profitable technology. Bangladesh Agricultural Research Institute and SFFP, Department of Agricultural Extension. 1-10 pp.

Hussain, M. J., Khan, M. A. H., Ali, M.Y., Quayyum, M. A. and Choudury, D. A., 
2010. Effect of urea super granule on the yield and yield attributes of cauliflower (Brassica oleracea var. botrytis). Bangladesh Journal of Agriculture, 35(1): 17-22.

Hussain, Md. 2004. Effect of nitrogen and boron on the yield and hollow stem disorder of broccoli. M. S. Thesis, Dept. Soil Science, Bangabandhu Sheikh Mujibur Rahman Agricultural University Gazipur.

Hussain M. J., Sirajul Karim, A. J. M., Solaiman, A. R. M. and Haque, M. M., 2012. Effects of Nitrogen and Boron on the Yield and Hollow Stem Disorder of Broccoli (Brassica oleracea var. Italica). The Agriculturists 10 (2):36-45.

Khalil M. I., Schmidhalter, U., Gutser, R. and Heuwinkel, H., 2011. Comparative efficacy of urea fertilization via super granules versus prills on nitrogen distribution, yield response and nitrogen use efficiency of spring wheat. Journal of Plant Nutrition, 34 (6):779-797.

Khalil M. I., Buegger, F., Schraml, M., Gutser, R., Richards, K. G. and Schmidhalter, U., 2009. Gaseous Nitrogen Losses from a Cambisol cropped to spring wheat with urea sizes and placement depths. In soil fertility \& plant nutrition. Soil Science Society of America Journal, 73(4):13351344.

Khalil, M. I., Schmidhalter, U. and Gutser, R., 2006. $\mathrm{N}_{2} \mathrm{O}, \mathrm{NH}_{3}$ and $\mathrm{NOx}$ emissions as a function of urea granule size and soil type under aerobic conditions. Water Air and Soil Pollution, 175:127-148.

Lawlor D.W., 2002. Carbon and nitrogen assimilation in relation to yield: mechanisms are the key to understanding production systems. Journal of Experimental Botany, 53(370): 773-787.

Liu, L., Shelp, B. J. and Spiers, G. A., 1993. Boron distribution and translocation in field-grown broccoli (Brassica oleracea var. italica). Canadian Journal of Plant Science, 73: 587-600.

Mohanty, S. K., Singh, U., Balasubramanian, V. and Jha, K. P. 1999. Nitrogen deep placement technologies for productivity, profitability, and environmental quality of rainfed lowland systems. Nutrition Cycle in Agroecosystems, 53:43-57.

Moniruzzaman M, Rahman S. M. L., Kibria M., Grahman M. A., Hossain M. M., 2007. Effect of boron and nitrogen on yield and hollow stem of broccoli. Journal of Soil and Nature, 1(3):24-29.

Mukherjee, S, K., 1986. Chemical technology for producing fertilizer nitrogen in the year 2000. Global aspects of food production. Inernational Rice Research Institute, Tycooly International, 227-237 pp.

Nazrul, M. I., Rahman, M. A., Choudhury, D. A. and Quayyum, M. A., 2007. Effect of different time and depths of USG application on growth and yield of cabbage. Bangladesh Journal of Agricultural Research, 32(2):301-306.

Ouda, B. A. and Mahadeen, A.Y., 2008. Effect of fertilizers on growth, yield, yield components, quality and certain nutrient contents in broccoli (Brassica oleracea). International Journal of Agriculture \& Biology, 10(6): 627-32

Perrin, P. K., Winkelman, D. L., Moseardi, E. R. and Anderson, J. R., 1979. Farm agronomic data for farmer's recommendation. Information bulletin 27 . CIMMYT, Mexico.

Rahman, M. A., Akand, M. H., Rahman, M. M. and Ali, M. Y., 2004. Effect of urea super granule and prilled urea application on agro-economic performance of potato. Journal of Agricultural Education Technology, 6(1\&2): 17-20.

Rashid, M. A., Billah, K. A., Mazid, M. A. and Jameel, F., 1996. Nitrogen use efficiency 
of urea super granules and prilled urea in irrigated rice cultivation. Bangladesh Rice Journal, 7:41-44.

Sarker, M. M. R., Shaheb, M. R. and Nazrul, M. I., 2012. Urea Super Granule: A good source of nitrogen on growth yield and profitability of cabbage in Sylhet. Journal of Environmental Science and Natural Resources, 5(1): 295-299.

Shangguan, Z., Shao, M., Dyckmans, J., 2000. Effects of nitrogen nutrition and water deficit on net photosynthetic rate and chlorophyll fluorescence in winter wheat. Journal of Plant Physiology, 156: 46-51.

Talukder M. A. H., Mannaf, M. A, Jabber, S. M. A., Islam, M. B., Kamal, S. M. A. H. M. and Saha, A. K., 2004. Effect of urea super granule as a source of nitrogen on the growth and yield of tomato. Pakistan journal of Biological sciences, 7(12):2078-2081.

Thakur, O. P., Sharma, P. P. and Singh, K. K., 1991. Effect of nitrogen and phosphorus with and without boron on curd yield and stalk rot incidence in cauliflower. Vegetable Science, 18(2): 115-121.
Tremblay, N. and Beaudet, P., 2006. Soil $\mathrm{N}_{\min }$ content and $\mathrm{P}_{2} \mathrm{O}_{5}$ export from vegetable crops in Quebec (Canada). Acta Horticulture, 700: 185-189.

Wojciechowska R., 2002. The nitrate and nitrite reductase activity in cabbage (Brassica oleracea var. capitata) as related to nitrate content modified by different nitrogen fertilization. Vegetable crops research bulletin, 56: 31-38.

Yoldas, F., S. Ceylan, Yagmur, B. and Mordogan, N., 2008. Effect of nitrogen fertilizer on yield quality and nutrient content in broccoli. Journal of Plant Nutrition, 31: 1333-43.

Zaman, S. K., Razzaque, M. A., Karim, S. M. R. and Ahmed, A. U., 1993. Evaluation of prilled urea and urea super granule as nitrogen sources for upland aus rice. Bangladesh Rice Journal, 4:42-46.

Zebarth, B. J., Bowen P. A. and Toivonen, P. M. A., 1995. Influence of nitrogen fertilization on broccoli yield, nitrogen accumulation and apparent fertilizernitrogen recovery. Canadian Journal of Plant Science, 75(3): 717-725. 